\title{
Analisis Energi Panas Pada Alat Pengeringan Gabah Tipe Swirling Fluidized Bed
}

\author{
Satya Andika Putra *, Novrinaldi \\ Pusat Penelitian Teknologi Tepat Guna, Lembaga Ilmu Pengetahuan Indonesia \\ Jl. K.S. Tubun no.5 Subang, Jawa Barat, Indonesia 41213
}

\begin{abstract}
Abstrak
Gabah merupakan produk hasil pertanian berupa biji-bijian yang proses pengeringannya mayoritas masih menggunakan cara tradisional yaitu dengan menghamparkan langsung dibawah sinar matahari. Pengeringan seperti ini tidak sesuai ketika musim hujan karena proses pengeringan gabah tidak berlangsung dengan baik sehingga kualitas gabah menurun. Solusinya adalah dengan menggunakan pengering. Salah satu tipe pengering yang dapat digunakan untuk gabah adalah pengering tipe swirling fluidized bed (SFB). Alat pengeringan gabah tipe SFB terdiri dari ruang pengeringan dan ruang plenum dengan diameter $400 \mathrm{~mm}$, selubung tengah pada ruang pengeringan berbentuk kerucut dengan diameter $300 \mathrm{~mm}$, selubung tengah ruang plenum berbentuk silinder diameter $300 \mathrm{~mm}$, distributor terletak diantara ruang pengeringan dan plenum yang terdiri dari 100 sudu dengan kemiringan $45^{\circ}$, dan dua saluran masuk udara berbentuk silinder yang masing-masing dilengkapi dengan pemanas dan blower dengan laju udara suplai $12 \mathrm{~m}^{3} /$ menit. Artikel ini menyajikan analisis energi panas pada alat pengeringan gabah tipe SFB. Analisis dilakukan secara teoretis berdasarkan prinsip-prinsip termodinamika dan perpindahan panas dengan menggunakan beberapa data hasil pengujian. Data diperoleh dari mengeringkan 300 gram gabah jenis Ciherang selama 60 menit. Hasil analisis menunjukkan bahwa energi yang dibutuhkan untuk mengeringkan gabah dari kadar air 26,8 \% menjadi 13,78 \% adalah sebesar 121.756,04 J. Laju perpindahan panas dari udara pengering ke gabah sebesar 780,28 W. Sedangkan energi panas yang harus disuplai oleh pemanas adalah sebesar 3943,86 W.
\end{abstract}

Kata kunci: pengering; gabah; swirling fluidized bed; energi pengeringan; perpindahan panas.

\begin{abstract}
[Title: Analysis of Heat Energy for Rough Rice Drying on Swirling Fluidized Bed Dryer] Rough rice is one of the grain agricultural products that the majority still uses solar drying. This drying method is not suitable during the rainy season because of slowly drying rate. In this season, a dryer is required to drying of rough rice. One type of dryer that can be used for rough rice is a swirling fluidized bed dryer (SFBD). The SFBD consists of a drying chamber and a plenum chamber with a diameter of $400 \mathrm{~mm}$, a cone center body of a drying chamber with a diameter of $300 \mathrm{~mm}$, a cylinder center body of a plenum chamber with a diameter of $300 \mathrm{~mm}$, a distributor located between the drying chamber and plenum chamber consisting of 100 blade with a slope of $45^{\circ}$ to horizontal, and two air inlet which are each equipped with a heater and blower with a supply air rate of $12 \mathrm{~m}^{3} /$ minute. This article present analysis of heat energy of SFBD rough rice drying. Analysis was conducted theoretically based on thermodynamic principles and heat transfer based on several experiment data. The drying process was carried out by 300 grams of Ciherang rough rice for 60 minutes. The analysis results showed that the heat energy to drying the rough rice is $121,756.04 \mathrm{~J}$. The heat transfer rate from air to rough rice is $780.28 \mathrm{~W}$. The heat energy requirement of a heater is $3943.86 \mathrm{~W}$.
\end{abstract}

Keywords: dryer; rough rice; swirling fluidized bed; heat energy drying; heat transfer.

\footnotetext{
${ }^{*}$ Penulis Korespondensi.

E-mail: satya.andika.p@gmail.com
}

doi: 10.14710/teknik.v40n2.62602 


\section{TEKNIK, 40 (2), 2019, 85}

\section{Pendahuluan}

Padi merupakan komoditas hasil pertanian yang menjadi makanan pokok masyarakat Indonesia. Tanaman padi dapat ditemukan hampir di seluruh wilayah daratan Indonesia. Produksi padi mengalami peningkatan dari tahun 2014 ke tahun 2015 yaitu dari 70.846.465 ton menjadi 75.397.841 ton (Badan Pusat Statistik, 2016). Padi menjadi makanan pokok tidak hanya karena kandungan pati yang tinggi sebagai sumber energi utama namun juga karena kandungan protein dan lemak.

Beberapa proses penanganan pascapanen padi diperlukan untuk menghasilkan produk yang siap konsumsi, seperti proses perontokan untuk memisahkan gabah dari malainya, proses pengeringan gabah untuk mengurangi kadar air di dalam gabah, proses penampian (pembersihan gabah dari kotoran), proses pengemasan atau penyimpanan dan proses penggilingan untuk memisahkan kulit gabah serta penyosohan untuk menghasilkan beras putih yang siap untuk dikonsumsi (Ahmad \& Budiastra, 2019). Proses pengeringan gabah merupakan salah satu proses yang menentukan kualitas gabah karena berhubungan dengan proses penyimpanan dan proses penggilingan. Pengeringan merupakan proses pengurangan kadar air suatu bahan sampai pada batas tertentu secara termal (Mujumdar, 2006). Proses pengeringan akan memperlambat pertumbuhan bakteri dan jamur sehingga gabah tidak akan cepat mengalami kerusakan dan penyusutan selama penyimpanan (Napitu, 2016). Gabah yang diperuntukkan untuk disimpan atau dikenal dengan gabah kering simpan (GKS) mempunyai standar kadar air antara 14\% hingga 18\%. Sedangkan untuk keperluan proses penggilingan dikenal dengan gabah kering giling (GKG) yang mempunyai standar kadar air maksimal 14\% (Napitu, 2016).

Proses pengeringan gabah di Indonesia masih banyak memakai cara konvensional yaitu dengan cara dijemur langsung dibawah sinar matahari, sehingga teradapat kendala pada saat musim hujan. Pada musim hujan pengeringan gabah kurang sempurna dan memerlukan waktu yang lebih lama apabila dibandingkan dengan musim kemarau. Pengeringan gabah yang kurang sempurna akan menyebabkan kualitas gabah akan menurun, pada saat penyimpanan maupun proses penggilingan menjadi beras. Diantara solusi untuk permasalahan tersebut adalah dengan menyediakan teknologi peralatan pengeringan gabah. Penggunaan pengering akan memerlukan biaya tambahan pada saat proses pengeringan, diperlukan biaya investasi awal dan juga biaya selama proses pengoperasian alat, akan tetapi proses pengeringan dengan menggunakan pengering akan memperkecil resiko kehilangan hasil (Napitu, 2016). Selain itu pengeringan menggunakan pengering akan mengurangi resiko gabah terkontaminasi bahan asing seperti debu dan lain-lain.

Ada beberapa teknologi pengeringan gabah diantaranya adalah dengan menggunakan pengering tipe rotari (rotary dryer) dan pengering hamparan fluidisasi (fluidized bed dryer). Pengering hamparan fluidisasi lebih unggul dibandingkan dengan pengering tipe rotari karena biaya investasi dan pemeliharaannya lebih rendah (Devahastin, 2001). Sebagian masyarakat Indonesia juga telah menggunakan pengering hamparan fluidisasi untuk mengeringkan gabah. Saat ini pengering hamparan fludisasi terus dikembangkan untuk mendapatkan efektifitas pengeringan yang lebih baik. Salah satu hasil pengembangan tersebut adalah pengering tipe swirling fluidized bed (SFB) yang juga dapat digunakan untuk mengeringkan material berbentuk butiran (Fanani dan Prabowo, 2014), tandan dan daun sawit (Mohideen, Faiz, Salleh, Hamidon, dan Raghavan, 2011).

Pengering tipe SFB mempunyai kesamaan prinsip kerja dengan pengering hamparan fluidisasi sehingga dapat digunakan untuk mengeringkan gabah atau biji-bijian. Gabah jenis Ciherang mempunyai diameter ekuivalen 3,66 mm (Putra, 2018) sehingga masuk ke dalam kategori partikel Geldart tipe-D. Pengering tipe SFB mempunyai kemampuan yang baik dalam kualitas fluidisasi untuk partikel Geldart tipe-D (Mohideen, Seri, \& Raghavan, 2012). Hal ini juga didukung oleh penelitian Venkiteswaran, Jun, Sing, Sulaiman, dan Raghavan (2012) yang menyatakan bahwa pengering tipe SFB mempunyai efektifitas pengeringan yang lebih baik dibandingkan dengan pengering hamparan fluidisasi, hal ini disebabkan oleh kualitas fluidisasi yang lebih baik.

Pengering tipe SFB terdiri dari dinding luar berbentuk tabung, tabung dalam (center body), distributor (annular distributor) yang terdiri dari sejumlah sudu (blade) dengan sudut kemiringan tertentu terhadap bidang horisontal (Sreenivasan dan Raghavan, 2002), saluran pengumpan bahan, saluran udara masuk, pemanas dan blower. Terdapat dua ruangan yaitu ruang plenum yang terletak pada bagian bawah distributor sebagai tempat masuk saluran udara dan ruang pengeringan yang terletak pada bagian atas distributor sebagai tempat untuk mengeringkan bahan. Prinsip kerja pengering tipe SFB yaitu udara pengering masuk ke dalam hamparan (bed) dengan sudut kemiringan tertentu (sudu) terhadap bidang horisontal distributor sehingga akan menghasilkan kecepatan tangensial dan memberikan efek pencampuran pada hamparan (Mohideen, Sreenivasan, Sulaiman, dan Raghavan, 2012). Kecepatan tangensial tersebut akan membuat bahan berputar mengelilingi selubung tengah sampai pada batas kadar air yang diinginkan. 


\section{TEKNIK, 40 (2), 2019, 86}

Akhir-akhir ini telah dilakukan penelitian terkait dengan pengering tipe SFB diantaranya adalah Othman, Wahab, dan Raghavan (2008) dan Hafiz, Batcha, dan Asmuin (2013) mengkaji tentang ruang plenum dengan metode numerik; Faizal, Seri, Ezamuddin, dan Raghavan (2012) mengkaji tentang distributor dengan metode numerik; Mohideen, Sreenivasan, dkk., (2012) mengkaji perpindahan panas untuk partikel Geldart tipeD secara eksperimental; Oktianto dan Prabowo (2014) dan Simanjuntak, Ichsani, Widodo, dan Sefriko (2016) mengkaji tentang sudut kemiringan sudu secara eksperimental; Permana dan Prabowo (2016) mengkaji tentang kecepatan udara masuk secara ekperimental; dan Sreenivasan dan Raghavan (2002) mengkaji hidrodinamis aliran udara secara eksperimental. Di Indonesia, penelitian pengering tipe SFB belum banyak dilakukan, khususnya untuk hasil pertanian berupa bijibijian.

Analisis energi pengeringan perlu dilakukan untuk mengetahui seberapa besar energi yang dibutuhkan pada saat proses pengeringan suatu bahan. Energi pengeringan pada pengering tipe fluidisasi terdiri dari energi yang dikonsumsi oleh blower dan energi yang dikonsumsi oleh pemanas (Sitompul, Sumardiono, dan Saryanto, 2001). Diantara tujuan dari analisis energi panas adalah untuk mengetahui seberapa besar energi yang dibutuhkan oleh pemanas dalam proses pengeringan. Pada penelitian ini akan dilakukan analisis energi panas pada proses pengeringan gabah menggunakan pengering tipe SFB dengan pendekatan teoretis berdasarkan prinsip-prinsip termodinamika dan perpindahan panas berdasarkan data hasil pengujian dan data sekunder. Hasil analisis tersebut digunakan untuk mengevaluasi desain pengering gabah tipe SFB.

\section{Bahan dan Metode}

Penelitian terkait dengan analisis energi panas pada proses pengeringan telah dilakukan oleh (Yulita, Murad, dan Sukmawaty, 2016) pada proses pengeringan manisan pepaya menggunakan pengering tipe rak. Pada penelitian tersebut energi panas dianalisis dengan metode eksperimental menggunakan pendekatan kesetimbangan energi. Pada penelitian ini, energi panas pengeringan dianalisis dengan menggunakan pendekatan teoretis prinsip-prinsip termodinamika dan perpindahan panas berdasarkan data hasil pengujian dan data sekunder.

\section{Pengujian dan Data}

Pengujian pengeringan gabah dilakukan untuk mendapatkan data yang diperlukan dalam perhitungan analisis energi panas. Pengujian dilakukan dengan mengeringkan gabah jenis Ciherang sebanyak 300 gram selama 60 menit menggunakan pengering tipe SFB. Pengering tipe SFB yang digunakan mempunyai dua saluran masuk udara (inlet), distributor terdiri dari 100 sudu (blade) dengan sudut kemiringan $45^{\circ}$ dari bidang horisontal, diameter dinding (cover) $400 \mathrm{~mm}$, diameter selubung tengah (center body) $300 \mathrm{~mm}$ dengan bentuk kerucut pada bagian ujungnya (pada ruang pengeringan), daya pemanas total 5.000 Watt dan daya blower sentrifugal total 3.200 Watt.

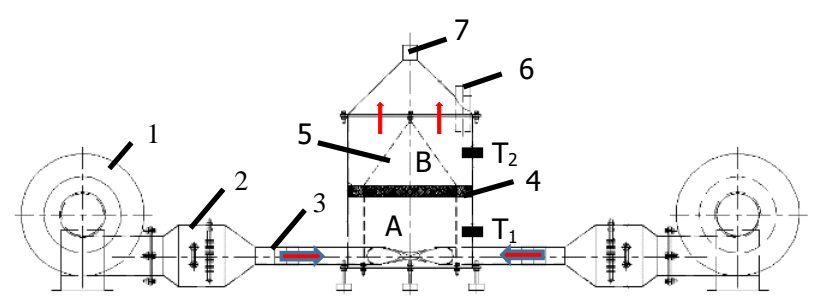

Gambar 1. Skema pengering gabah tipe SFB

Keterangan :

1. Penyuplai udara (Blower)

2. Pemanas

3. Saluran udara masuk (inlet)

4. Distributor

5. Selubung tengah (center body)

6. Saluran pengumpan gabah

7. Saluran udara keluar

A. Ruang plenum

B. Ruang pengeringan

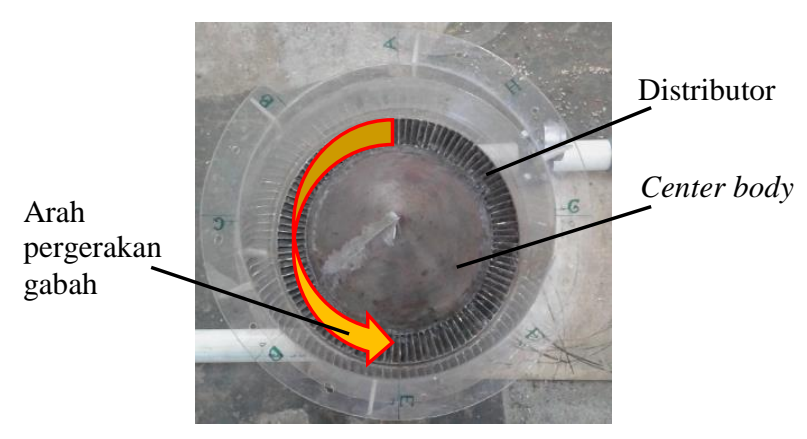

Gambar 2. Ruang pengeringan pada pengering gabah tipe SFB

Data hasil pengujian yang diperlukan untuk perhitungan analisis energi panas berupa : suhu udara pengering $\left(T_{2}\right)$, suhu gabah awal $\left(T_{g b}\right)$, suhu gabah akhir $\left(T_{g k}\right)$, suhu lingkungan $\left(T_{L}\right)$, kadar air gabah awal $\left(M_{b}\right)$, kadar air gabah akhir $\left(M_{k}\right)$, kecepatan rata-rata udara pengering $\left(v_{u}\right)$, laju alir (debit) udara pengering dari blower $\left(Q_{b}\right)$ dan sudut kemiringan sudu $(\theta)$.

Sedangkan data sekunder yang diperlukan untuk analisis energi panas berupa : panas jenis gabah $\left(C_{p g}\right)$, diameter ekuivalen gabah $\left(d_{p g}\right)$, massa satu butir gabah $\left(m_{g}\right)$, panas laten penguapan air $\left(\lambda_{a}\right)$, bilangan Prandtl 


\section{TEKNIK, 40 (2), 2019, 87}

udara pengering (Pr), konduktifitas panas udara pengering $\left(k_{u}\right)$, viskositas kinematik udara pengering $\left(v_{u}\right)$, panas jenis udara pengering $\left(C_{p u}\right)$ dan massa jenis udara pengering $\left(\rho_{u}\right)$.

Pengukuran suhu udara pengering menggunakan Termokopel (Thermocouple) tipe $\mathrm{K}$ dihubungkan dengan data logger merk Omega. Kecepatan udara pengering diukur menggunakan digital anemometer, data kecepatan tersebut kemudian digunakan untuk perhitungan laju alir udara pengering. Sedangkan kadar air gabah diketahui dengan melakukan pengukuran kadar air berdasarkan metode ASTM D5142.

\section{Energi Panas Pengeringan Gabah}

Dalam pengeringan gabah terdapat dua tahapan proses yaitu proses pemanasan gabah dan proses penguapan kandungan air dalam gabah. Menurut (Taib, Said, dan Wiraatmadja, 1988) energi panas untuk mengeringkan suatu bahan dapat dihitung dengan menggunakan Persamaan 1.

$$
q_{p b}=q_{s b}+q_{1 b}
$$

dengan :

$q_{p b}$ : Energi panas yang dibutuhkan mengeringkan gabah [J]

$q_{s b} \quad$ : Energi untuk memanaskan gabah [J]

$q_{l b}$ : Energi untuk menguapkan air dalam gabah $[\mathrm{J}]$

energi untuk memanaskan gabah dihitung dengan Persamaan 2.

$$
q_{s b}=m_{g} C_{p g} \Delta T
$$

dengan :

$m_{g} \quad$ : Massa gabah yang dikeringkan $[\mathrm{kg}]$

$C_{p g}$ : Panas jenis gabah yang dikeringkan $[\mathrm{J} / \mathrm{kg} \mathrm{K}]$

$\Delta T$ : Perbedaan suhu bahan awal dan target $\left[{ }^{\circ} \mathrm{C}\right]$

sedangkan energi untuk menguapkan kandungan air dalam gabah dihitung dengan Persamaan 3.

$$
q_{i b}=m_{a g} \lambda_{a}
$$

dengan :

$m_{a b}$ : Massa air yang diuapkan dalam bahan $[\mathrm{kg}]$

$\lambda_{a}:$ Panas laten penguapan air $[\mathrm{J} / \mathrm{kg}]$

\section{Laju Perpindahan Panas}

Diantara parameter yang perlu diketahui dalam analisis energi panas dalam proses pengeringan gabah yaitu laju perpindahan panas dari udara pengering ke gabah. Hal ini berguna untuk mengetahui laju energi maksimal yang diberikan oleh udara pengering ke gabah sehingga dapat digunakan untuk menentukan laju energi yang harus disuplai ke ruang pengeringan.

Laju perpindahan panas dari udara pengering ke gabah dihitung dengan pendekatan kasus aliran udara melewati bahan berbentuk bola (flow over a sphere) dengan asumsi bahwa gabah berbentuk bola dengan diameter ekuivalen $(d p)$, suhu pada permukaan gabah dianggap seragam, proses perpindahan panas terjadi dalam kondisi tunak. Untuk kasus tersebut, perhitungan menggunakan Persamaan 4 (Incropera, Dewitt, Bergman, dan Lavine, 2007).

$$
q_{u b}=\bar{h} A\left(T_{u}-T_{b}\right)
$$

dengan :

$q_{u b}$ : Laju perpindahan panas dari udara ke bahan yang dikeringkan [W]

A : Luas permukaan gabah [m2]

$\bar{h} \quad$ : Koefisien perpindahan panas konveksi rata-rata [W/m2 K]

$T_{u}\left(T_{2}\right)$ : Suhu udara pengering $\left[{ }^{\circ} \mathrm{C}\right]$

$\mathrm{Tb}$ : Suhu bahan $\left[{ }^{\circ} \mathrm{C}\right]$

Koefisien perpindahan panas konveksi $(\bar{h})$ dapat dicari dengan menggunakan pendekatan nilai bilangan Nusselt $\left(\overline{\mathrm{Nu}}_{D}\right)$ (Persamaan 5), yang direkomendasikan oleh Whitaker (Incropera dkk., 2007).

$\overline{N u}_{D}=2+\left(0,4 R e_{D}{ }^{1 / 2}+0,06 \operatorname{Re}_{D}{ }^{2 / a}\right) \operatorname{Pr}^{0,4}\left(\frac{\mu}{\mu_{a}}\right)^{1 / 4}$

dengan :

$R e D$ : Bilangan Reynolds udara pengering

$\operatorname{Pr} \quad$ : Bilangan Prandtl udara pengering

$\mu \quad$ : Viskositas udara pengering $\left(\mathrm{Ns} / \mathrm{m}^{2}\right)$

$\mu s$ : Viskositas udara pada permukaan bahan $\left(\mathrm{Ns} / \mathrm{m}^{2}\right)$

\section{Energi Pemanas}

Energi yang harus disuplai oleh pemanas dapat dihitung berdasarkan laju perpindahan panas (laju energi) antara udara pengering dengan gabah $\left(q_{u b}\right)$. Dengan mengetahui udara pengering di dalam ruang pengeringan $\left(T_{2}\right)$ dan laju perpindahan panas udara pengering ke gabah maka suhu udara yang harus disuplai oleh pemanas $\left(T_{o, p}\right)$ dapat diketahui dengan menggunakan persamaan energi panas dalam kondisi tunak (steady-flow thermal energy equation). Dengan begitu laju energi pada pemanas dapat dihitung dengan menggunakan Persamaan 6 (Incropera dkk., 2007).

$$
q_{u, h}=m_{u} C_{p, u}\left(T_{i, p}-T_{0, p}\right)
$$

dengan :

$q_{u, h}:$ Laju energi pada pamanas [W] 


\section{TEKNIK, 40 (2), 2019, 88}

$\dot{m}_{u} \quad$ : Laju alir massa udara $[\mathrm{kg} / \mathrm{s}]$

$C_{p, u}:$ Panas jenis udara [J/kg K]

$T_{i, p} \quad$ : Suhu udara saat masuk pemanas $\left[{ }^{\circ} \mathrm{C}\right]$

$T_{o, p}$ : Suhu udara saat keluar dari pemanas $\left[{ }^{\circ} \mathrm{C}\right]$

Semua perhitungan energi panas pengeringan dihitung dengan mengasumsikan bahwa dinding bagian luar ruang plenum dan ruang pengeringan, dinding pada saluran udara masuk maupun dinding pada ruang pemanas diisolasi dengan baik, sehingga kehilangan energi melalui dinding dapat diabaikan.

\section{Hasil dan Pembahasan}

Data hasil pengujian pengeringan 300 gram gabah selama 60 menit dapat dilihat pada Tabel 1.

Tabel 1. Data pengujian pengeringan gabah

\begin{tabular}{ll}
\hline \multicolumn{1}{c}{ Uji } & \multicolumn{1}{c}{ Hasil } \\
\hline Suhu udara pengering $\left(T_{u}\right.$ atau $\left.T_{2}\right)$ & $47^{\circ} \mathrm{C}$ \\
Suhu gabah, awal $\left(T_{g b}\right)$ & $26^{\circ} \mathrm{C}$ \\
Suhu gabah, akhir $\left(T_{g k}\right)$ & $45^{\circ} \mathrm{C}$ \\
Suhu lingkungan $\left(T_{L}\right)$ & $33^{\circ} \mathrm{C}$ \\
Kadar air gabah, awal $\left(M_{b}\right)$ & $26,8 \%$ \\
Kadar air gabah, akhir $\left(M_{k}\right)$ & $13,78 \%$ \\
Kecepatan rata-rata udara pengering $\left(v_{u}\right)$ & $9 \mathrm{~m} / \mathrm{s}$ \\
Laju alir udara pengering $\left(Q_{b}\right)$ & $12 \mathrm{~m}^{3} /$ menit \\
Sudut kemiringan sudu $(\theta)$ & $15^{\circ}$ \\
Daya pemanas (total) & $4070 \mathrm{~W}$ \\
\hline
\end{tabular}

Dari data pengujian diketahui bahwa kadar air gabah setelah pengeringan telah sesuai dengan standar mutu untuk gabah kering simpan yaitu dengan kadar air antara $14 \%$ hingga $18 \%$, dan juga telah sesuai dengan standar mutu gabah kering giling dengan kadar air maksimal $14 \%$.

Sedangkan data sekunder yang diperlukan untuk perhitungan analisis energi panas pengeringan gabah terlihat pada Tabel 2.

Tabel 2. Data sekunder perhitungan energi panas pengeringan

\begin{tabular}{|c|c|}
\hline Uji & Hasil \\
\hline Panas jenis gabah $\left(C_{p g}\right)^{\mathrm{a}}$ & $2146 \mathrm{~J} / \mathrm{kgC}$ \\
\hline Massa satu butir gabah $\left(m_{g}\right)^{\mathrm{b}}$ & $0,0305 \mathrm{~g}$ \\
\hline Diameter ekuivalen gabah $\left(\mathrm{d}_{\mathrm{p}}\right)^{\mathrm{b}}$ & $3,66 \mathrm{~mm}$ \\
\hline Panas laten penguapan air $\left(\lambda_{a}\right)^{\mathrm{c}}$ & $2.402 .000 \mathrm{~J} / \mathrm{kg}$ \\
\hline Bilangan Prandtl udara pengering $(P r)^{\mathrm{c}}$ & 0,7051975 \\
\hline Konduktifitas panas udara pengering $\left(k_{u}\right)^{\mathrm{c}}$ & $0,0272528 \mathrm{~W} / \mathrm{mK}$ \\
\hline Viskositas kinematik udara pengering $\left(v_{u}\right)^{\mathrm{c}}$ & $1,719 \times 10^{-5} \mathrm{~m}^{2} / \mathrm{s}$ \\
\hline Panas jenis udara pengering $\left(C_{p u}\right)^{\mathrm{c}}$ & $1,007436 \mathrm{~kJ} / \mathrm{kgK}$ \\
\hline Massa jenis udara pengering $\left(\rho_{u}\right)^{\mathrm{c}}$ & $1,1121456 \mathrm{~kg} / \mathrm{m}^{3}$ \\
\hline \multicolumn{2}{|l|}{ a (Iguaz dkk., 2003) } \\
\hline \multicolumn{2}{|l|}{ b (Putra, 2018) } \\
\hline \multicolumn{2}{|l|}{${ }^{\mathrm{c}}$ (Incropera dkk., 2007) } \\
\hline
\end{tabular}

Panas laten penguapan air $\left(\lambda_{a}\right)$ didapatkan dengan menggunakan data suhu rata-rata gabah yaitu $35,5^{\circ} \mathrm{C}$. Sedangkan Bilangan Prandtl $(\mathrm{Pr})$, konduktivitas panas $\left(k_{u}\right)$ dan viskositas kinematik $\left(v_{u}\right)$ udara pengering didapatkan dengan menggunakan data pada suhu film antara udara pengering dengan gabah yaitu $40,25{ }^{\circ} \mathrm{C}$. Panas jenis dan massa jenis udara pengering digunakan untuk menghitung suhu udara pengering yang disuplai oleh pemanas $\left(T_{o, p}\right)$ dan laju energi pada pemanas $\left(q_{u, h}\right)$, panas jenis dan massa jenis yang tertera pada tabel 2 adalah untuk perhitungan laju energi pada pemanas dengan suhu rata-rata udara $41,8{ }^{\circ} \mathrm{C}$. Sedangkan untuk menghitung suhu udara pengering yang disuplai oleh pemanas $\left(T_{o, p}\right)$ menggunakan data panas jenis dan massa jenis udara pengering pada suhu rata-rata udara pengering pada ruang pengeringan $\left(T_{u}\right)$ dengan udara pengering yang disuplai oleh pemanas $\left(T_{o, p}\right)$ yaitu sebesar $1,007872 \mathrm{~kJ} / \mathrm{kgK}$ dan $1,0888 \mathrm{~kg} / \mathrm{m}^{3}$.

Proses pengeringan $300 \mathrm{~g}$ gabah selama 60 menit dapat menurunkan kadar air gabah dari $26,6 \%$ menjadi $13,78 \%$ sehingga sebanyak 45,303 gram kandungan air dalam gabah mengalami proses penguapan. Energi yang diperlukan untuk menguapkan kandungan air tersebut sebesar 109.523,84 J. Sedangkan suhu gabah naik dari $26{ }^{\circ} \mathrm{C}$ menjadi $45{ }^{\circ} \mathrm{C}$, hal ini menunjukkan adanya energi yang digunakan untuk memanaskan gabah sebesar 12.232,2 J. Sehingga jumlah energi untuk mengeringkan $300 \mathrm{~g}$ gabah adalah sebesar 121.756,04 J.

Proses kenaikan suhu gabah selama proses pengeringan juga menunjukkan adanya transfer energi dari udara pengering ke gabah. Berdasarkan data hasil pengujian, suhu udara pengering pada ruang pengeringan selama proses pengeringan cenderung stabil yaitu rata-rata sebesar $47^{\circ} \mathrm{C}$. Selama proses pengeringan yaitu selama 60 menit, transfer energi panas dari udara pengering hanya mampu menaikkan suhu gabah menjadi $45{ }^{\circ} \mathrm{C}$. Hal tersebut terjadi karena adanya laju perpindahan panas dari udara pengering ke gabah sebesar 780,28 W.

Untuk menjaga suhu ruang pengeringan $47{ }^{\circ} \mathrm{C}$ maka laju energi (perpindahan panas) dari udara pengering ke gabah $(780,28 \mathrm{~W})$ harus dipertahankan. Untuk mempertahankan kondisi tersebut maka besarnya laju energi udara pengering yang diberikan atau disuplai ke ruang pengeringan harus sama dengan laju perpindahan panas dari udara pengering ke gabah. Secara teoretis dengan menggunakan persamaan energi panas dalam kondisi tunak maka dapat diketahui bahwa untuk menjaga suhu ruang pengeringan $47{ }^{\circ} \mathrm{C}$ maka besarnya suhu udara pengering yang disuplai oleh pemanas $\left(T_{o, p}\right)$ adalah $50,6{ }^{\circ} \mathrm{C}$, dengan asumsi bahwa tidak ada kehilangan energi panas melalui dinding ruang pemanas, saluran udara masuk maupun dinding ruang plenum dan ruang pengeringan. Dengan demikan dapat diketahui bahwa laju energi yang diberikan oleh 


\section{TEKNIK, 40 (2), 2019, 89}

pemanas untuk memanaskan udara dari suhu lingkungan $\left(T_{L}\right) 33{ }^{\circ} \mathrm{C}$ menjadi $50,6^{\circ} \mathrm{C}$ adalah sebesar $3943,86 \mathrm{~W}$.

Selama proses pengeringan, daya listrik yang terukur pada pemanas adalah sebesar $4070 \mathrm{~W}$ sedangkan secara perhitungan teoretis $\left(q_{u, h}\right)$ adalah $3943,86 \mathrm{~W}$, sehingga terdapat selisih laju energi yaitu sebesar 126,14 W. Hal ini menunjukkan bahwa secara realita terjadi kehilangan energi udara pengering dari ruang pemanas hingga ruang pengeringan sebesar 3,09\%. Untuk mengoptimalkan kinerja pengering tersebut maka perlu ditambahkan isolator pada dinding ruang pemanas, saluran udara masuk, ruang plenum dan ruang pengeringan. Hal ini bertujuan untuk mengurangi kehilangan energi.

\section{Kesimpulan}

Diperlukan energi sebesar 121.756,04 J untuk mengeringkan 300 gram gabah dari kadar air 26,8\% menjadi $13,78 \%$. Selama proses pengeringan gabah terjadi perpindahan panas dari udara pengering ke gabah sebesar 780,28 W. Untuk menjaga supaya suhu pada ruang pengeringan tetap stabil pada $47{ }^{\circ} \mathrm{C}$ maka secara teoretis diperlukan pemanas dengan daya $3943,86 \mathrm{~W}$. Terjadi kehilangan energi pada dinding ruang pemanas, saluran udara masuk, ruang plenum dan ruang pengeringan. Untuk mengoptimalkan kinerja pada pengering tipe SFB dalam proses pengeringan gabah maka pada bagian tersebut perlu ditambahkan isolator.

\section{Ucapan Terima Kasih}

Terima kasih kepada Kementerian Riset, Teknologi dan Pendidikan Tinggi yang telah memberikan dana penelitian dalam program Karyasiswa Pendidikan Gelar Pascasarjana dan juga kepada Pusat Penelitian Teknologi Tepat Guna LIPI yang telah memberikan dana dan penggunaan fasilitas penelitian.

\section{Daftar Pustaka}

Ahmad, U., Budiastra, I. W. (2019). Teknologi Pengolahan Pasca Panen. Diambil dari http://web.ipb.ac.id/ usmanahmad/Penanganan padi.htm

Badan Pusat Statistik. (2016). Produksi Padi Menurut Provinsi. Diambil dari https://www.bps.go.id/linkTableDinamis/view/i $\mathrm{d} / 865$

Devahastin, S. (2001). Panduan Praktis Mujumdar untuk Pengeringan Industrial. Bogor: IPB Press.

Faizal, M., Seri, S., Ezamuddin, S., Raghavan, V. R. (2012). Numerical Investigation of Air Flow Distribution in a Swirling Fluidized Bed. Advance Material Research, 499, 132-137.

Fanani, Z., Prabowo. (2014). Studi Eksperimen Pengaruh Ukuran Partikel Batubara Pada
Swirling Fluidized Bed Dryer Terhadap Karakteristik Pengeringan Batubara. Jurnal Teknik POMITS, 3(1), B96-B99.

Hafiz, M. A., Batcha, M. F. M., Asmuin, N. (2013). Effect of plenum chamber depth in a swirling fluidized bed. Materials Science and Engineering, 50, 1-7.

Iguaz, A., Martin, M. B. S., Arroqui, C., Fernandez, T., Mate, J. I., Virseda, P. (2003). Thermophysical Properties of Medium Grain Rough Rice (LIDO Cultivar) at Medium and Low Temperatures. Eur Food Res Technol, 217, 224-229.

Incropera, F. P., Dewitt, D. P., Bergman, T. L., Lavine, A. S. (2007). Fundamentals of Heat and Mass Transfer (6th ed.). United States: John Wiley and Sons.

Mohideen, M. F., Faiz, M., Salleh, H., Hamidon, H., Raghavan, V. R. (2011). Drying of Oil Palm Frond via Swirling Fluidization Technique. Dipresentasikan pada World Congress on Engineering, London, U.K: WCE.

Mohideen, M. F., Seri, S., Raghavan, V. R. (2012). Fluidization of Geldart Type-D Particles in a Swirling Fluidized Bed, 8.

Mohideen, M. F., Sreenivasan, B., Sulaiman, S. A., Raghavan, V. R. (2012). Heat Transfer in Swirling Fluidized Bed with Geldart Type-D Particles. Korean J. Chem. Eng., 29(7), 862867.

Mujumdar, A. S. (2006). Handbook of Industrial Drying (Edisi ke-3). Boca Raton, Florida, Amerika Serikat: CRC Press Taylor \& Francis Group.

Napitu, Y. O. (2016). Desain Model Pengering Spouted Bed Dua Dimensi untuk Pengeringan Gabah (Tesis). Institut Pertanian Bogor, Bogor.

Oktianto, A. T., Prabowo. (2014). Studi Eksperimen Pengaruh Sudut Blade Tipe Single Row Distributor pada Swirling Fluidized Bed Coal Dryer terhadap Karakteristik Pengeringan Batubara. Jurnal Teknik POMITS, 3(1), B86B90.

Othman, S., Wahab, A. A., Raghavan, V. R. (2008). Numerical Study of the Plenum Chamber of a Swirling Fluidized Bed. Manufacturing Engineering, 6.

Permana, D., Prabowo. (2016). Studi Eksperimen Pengaruh Kecepatan Udara Pengering Inlet Chamber pada Swirling Fluidized Bed Dryer Terhadap Karakteristik Pengeringan Batu Bara. Jurnal Teknik ITS, V(2), B684-B689.

Putra, S. A. (2018). Perancangan Alat Pengering Gabah Tipe Swirling Fluidized Bed Skala Laboratorium (Tesis). Institut Teknologi Bandung, Bandung. 


\section{TEKNIK, 40 (2), 2019, 90}

Simanjuntak, M. E., Ichsani, D., Widodo, W. A., Sefriko, A. (2016). Experimental Study The Effect of Angle of Blade inclination on Coal Swirl Fluidized Bed Drying, 11(2), 7.

Sitompul, J. P., Sumardiono, S., Saryanto, M. W. (2001). Studi Analisis Efisiensi Energi dan Tekno Ekonomi Pengeringan Butiran Multi Tahap. Jurnal Mesin, XVI(1), 11-17.

Sreenivasan, B., Raghavan, V. R. (2002). Hydrodynamics of a swirling fluidised bed. Chemical Engineering and Processing, 8.
Taib, G., Said, G., Wiraatmadja, S. (1988). Operasi Pengeringan pada Pengolahan Hasil Pertanian (1 ed.). Jakarta: Mediyatama Sarana Perkasa.

Venkiteswaran, V. kumar, Jun, G. J., Sing, C. Y., Sulaiman, S. A., Raghavan, V. R. (2012). Variation of Bed Pressure Drop with Particle Shapes in Swirling Fluidized Bed. journal of Appllied Sciences, 12(24), 2598-2603.

Yulita, D., Murad, Sukmawaty. (2016). Analisis Energi Panas pada Proses Pengeringan Manisan Pepaya (Carica Papaya L.) Menggunakan Alat Pengering Tipe Rak. Jurnal Ilmiah Rekayasa Pertanian dan Biosistem, 4(1), 192-199. 